\title{
The Prospect of Dollarization in Nigeria: An Empirical Review
}

\author{
Uduakobong Edy-Ewoh, Babatunde Binuyo \\ Department of Economics, Veronica Adeleke School of Social Sciences, Babcock University, Ilishan Remo, Nigeria
}

Email address:

edy-ewohu@babcock.edu.ng (U. Edy-Ewoh)

\section{To cite this article:}

Uduakobong Edy-Ewoh, Babatunde Binuyo. The Prospect of Dollarization in Nigeria: An Empirical Review. International Journal of Business and Economics Research. Vol. 8, No. 4, 2019, pp. 220-231. doi: 10.11648/j.ijber.20190804.17

Received: June 13, 2019; Accepted: July 12, 2019; Published: July 26, 2019

\begin{abstract}
Dollarization has been perceived in literature as a strategy that could help emerging and developing economics achieve price stability via lower inflation rates occasioned by the adoption of a stronger currency. Supporters of dollarization also infer that the strategy has the ability to affect positively real economic variables such as growth and employment through its ability to lower interest rates, increase investment and eliminate currency risk thereby increasing international trade. In this study, we examined the effect of dollarization on selected macroeconomic variables in Nigeria from 1972 to 2017. Using simple regression models, we analysed the impact of real dollarization index on prime lending rates, inflation, unemployment, PCI, FDI, real GDP growth and total trade in Nigeria. Empirical results revealed that dollarization did not exert significant positive effect on the selected macroeconomic variables. The study therefore recommended that government should be intentional about putting measures in place to strengthen the Nigerian naira so that economic agents will see no need to hold their wealth in or transact with a foreign currency. This will discourage dollarization in Nigeria which is perceived to be a major driver of inflation in the country.
\end{abstract}

Keywords: Dollarization, Prospect, Macroeconomic Variables, Nigeria

\section{Introduction}

In the recent past, Nigeria has struggled with a declining economy. Data from the National Bureau of Statistics [1] revealed that the economy has been growing at an average of 1.8 per cent compared to the average growth of 5 per cent recorded between 2011 and 2015. One of the major menace in the economy has been the high and persisting inflationary trend in the country. Several attempts to curb inflation using monetary policy for instance has failed. Literature however posits that countries that give up the use of their domestic currency, and delegates the operations of their monetary policy to a more stable currency will tend to have lower inflation among other things. This process of surrender is termed dollarization.

Dollarization or currency substitution is the use of any foreign currency in place of or alongside a domestic currency. While the term might sound restrictive, dollarization is used in a broader sense to describe the adoption of a foreign currency in a domestic economy. Dollarization has been suggested as a policy that might, among other goals, promote international trade between a country and the country whose foreign currency is adopted and also drive economic development and prosperity particularly in developing countries [2-4]. There is increasing evidence that the use of a common currency may induces a substantive increase in trade, which in turn may fuel economic growth [5]. Studies show that a currency union increases bilateral trade among its members, and the effect is both large and statistically significant [6-7]. Dollarization has also been noted to affect nominal exchange rate, and prices level [8].

Dollarization is not official in Nigeria. However, since the 1980s, the U.S. dollar has been increasingly used as a medium of exchange within the Nigerian markets [9]. In 2012, the then CBN Governor, Sanusi Lamido Sanusi, decried the dollarization of the Nigeria economy, stating that the situation was becoming worrisome [10]. To stem the tide of dollarization, in a circular dated May 21, 2015 the Central Bank of Nigeria (CBN) affirmed that the pricing of goods and services in Nigeria shall continue to be in Naira only, implying that dollarization in all its forms was a criminal offence in Nigeria [11]. On March 14 2017, the Nation Newspaper reported that the House of Representatives 
resolved to probe foreign schools in Nigeria collecting fees in foreign currency [12]. This was in pursuant of Sections 15, 20 (1) and (5) of the CBN Act, which made it illegal to price or denominate the cost of any product or service in any foreign currency in Nigeria other than the Naira.

While the Nigeria government has not officially sanctioned the dollarization of the economy, the process appears to be gaining acceptance. The desire to hold foreign currency may be due to the incessant bouts of inflation and currency devaluation in the country which weakens the Naira, eroding its purchasing power and the value of personal wealth.

Some economists have argued that pursuing a dollarization strategy helps developing countries grow their economies through the stabilization of inflation, increased investment and trade opportunities. Others however discourage a dollarization strategy because it causes these economically vulnerable countries to relinquish control over their own monetary policy. Argument favouring dollarization is that it lowers interest rates and stimulates investment. The Nigerian economy over the years has been struggling with the problem of inflation and high level of unemployment arising from low levels of investment in the country. While it is presently considered as being undesirable for the economy, dollarization may proof to be the most viable solution to the problem of inflation and poor standard of living in Nigeria.

This work is unique because most studies on dollarization in Nigeria have been majorly interested in examining the extent and determinants of dollarization in the country with the exception of the work by [13], without looking at how dollarization influences macroeconomic variables in the country. This study filled this gap by computing a dollarization index for Nigeria and investigating its impact on selected macroeconomic variables in Nigeria. The variables of interest are lending rates, inflation, unemployment, PCI, FDI, real GDP growth and total trade which extends the scope of variables covered in earlier works [13].

The aim of this paper is therefore, to examine areas in which Nigeria might benefit should the country decides to dollarize the economy. The benefit is defined in relation to the signs of the coefficients of the selected macroeconomic variables. Structurally, the paper is arranged into five sections. Following the introductory section, section two provides a brief review of the concept of dollarization with highlights on its variants and also presents a theoretical literature on dollarization. Section three discusses the experiences of countries that has been dollarized to draw example for Nigeria and also a discuss on macroeconomic performance in Nigeria relative to dollarized economies. Section four discusses the methods, sources of data and results from empirical analysis while section five presents concluding remarks and recommendations.

\section{Conceptual and Theoretical Literature}

\subsection{Dollarization: Definition and Scope}

Dollarization can be described as a situation in which a foreign currency is replaces a country's currency in performing several functions of money [4]. When the inhabitants of a country use a foreign currency in parallel to or instead of their domestic currency, then the country is dollarized [14]. The concept also describes a dual-currency utilization since the term is more appropriately connected with the official designation of the United States dollar as the national currency or adopting a stronger foreign currency such as the United States Dollar, Euro, or Yen [15-16]. Summarily, dollarization means that the country adopts the currency of another country (for example, the dollar) as a means of payment and unit of account [17]. Therefore, while many people associate dollarization with the United States dollar, the association is not exclusive. The euro, South African rand, Russian rubble, New Zealand and Australian dollars, Japanese Yen are currencies that have been used by other countries.

Though dollarization and currency substitution are often used interchangeably, dollarization is most related to the use of foreign currency as a unit of account and a store of value but not necessarily as a medium of exchange while currency substitution primarily indicates the replacement of domestic currency by foreign currency as a medium of exchange [18]. It is however obvious that the two concepts are largely defined based on the relatedness to the three major functions of money [19]. Currency substitution can however be regarded as a subset of dollarization, which can also be defined as a process of substituting foreign currency for a domestic currency to fulfil the essential functions of money as medium of exchange (currency substitution), and/or as a store of value (asset substitution) [20]. Accordingly, dollarization comprises of both currency and asset substitution, and both are related to the functions of money as medium of exchange and store of value.

Dollarization is a generic term that can fall into different categories. It can be official or unofficial. Unofficial dollarization occurs when residents of a country hold a large share of their financial wealth in assets denominated in foreign currency, though the foreign currency lacks the legal tender privileges that domestic currency enjoys [21-22]. Unofficial dollarization has existed in many countries for years but has attracted little or no political attention because it is somewhat beyond the control of governments, though it constitutes a major issue of interest to economist [23]. Particularly in developing countries, foreign currencies such as the dollar is widely used and accepted in private transactions though it is not classified as legal tender by the country's government [24]. This makes its use unofficial.

An IMF study measuring unofficial dollarization by the ratio of foreign-currency deposits to the broad money supply (M2 or M3) found that in 1995, 18 countries had high unofficial dollarization (exceeding 30 percent), with the average degree of dollarization of 45 percent. Another 34 countries had a moderate unofficial dollarization, averaging about 16 percent of the broad money supply. However, unofficial dollarization was not limited to developing countries. For instance, foreign currency deposits were about 
22 percent of broad money in Greece and more than 15 percent even in the United Kingdom [21].

Unofficial dollarization is essentially the rational response of economic agents to a loss of confidence in the domestic economy, often resulting from episodes of inflation, currency devaluation and/or currency confiscation [22]. Unofficial dollarization may often be related to the growth of underground or unrecorded economic activities since currency, particularly foreign currency is often the preferred medium of exchange for such transactions [19].

Official dollarization or full dollarization is a complete monetary union with a foreign country from which a country "imports" a currency, by making the foreign currency full legal tender and reducing its own currency, if any, to a subsidiary role [25]. In officially dollarized countries, there is no domestic currency, no currency risk and, therefore, no risk of currency crises.

Full dollarization does not mean that a foreign currency is the only legal tender; freedom of choice provides some protection from being stuck using a foreign currency that becomes unstable [25]. It is more of a portfolio shift away from domestic currency to foreign currency, to fulfil the main functions of money - store of value, unit of account, and medium of exchange. It is typically a result of unstable macroeconomic conditions and a rational response of people seeking to diversify their assets in the face of heightened domestic currency risk [26-28]. Thus dollarization will mostly occur when there is high inflation and macroeconomic instabilities and particularly in vulnerable developing economies.

\subsection{Theoretical Literature}

Dollarization is a form of fixed exchange rate and a special case of monetary unification-a situation where some economies come together to adopt a common currency and establish a common central bank to which they surrender monetary authority. Monetary union is said to be desirable when the economies operate in an optimum currency area (OCA). An OCA describes an entire region where economic efficiency is maximized because they share a single currency. The theory of OCA postulates that countries that share strong economic ties (such as trading relationships) may benefit from a common currency.

This theory was formally presented in an article title "A Theory of Optimum Currency Areas," in 1961 by Robert Mundell [29]. The intent of the article was to address the economic criteria that would necessitate various regions of the world to adopt a common currency or engage in a monetary union. Mundell used factor (labour and capital) mobility as its most important criterion - principle or standard-which should necessitate the adoption of a common currency.

Mundell developed a cost-benefit analysis of the monetary union. He identified the benefits to include a reduction of the various transaction costs generated by the existence of various currencies and a gain in the liquidity of the currency, elimination of exchange-rate uncertainty, and enhanced credibility for the monetary authority. This gain he attributed mainly to the expansion of the currency's area of transactions. The inability of a country to conduct independent monetary policy which included loss of seignorage, inability to devalue or revalue domestic currency for stabilization purposes, the elimination of the exchange rate between participants in the union were identified as cost.

In Mundell's framework, the main force that favours a common currency is the transactions cost benefit associated with the exchange of goods or services and incurred in overcoming market imperfections. The use of the same money facilitates exchange of goods and services and also financial exchanges. The expansion of trade, or globalization, has revealed the increasing importance of the transaction cost benefit. [30].

The OCA theory was further extended as openness was identified as a superior criterion for pursuing currency union or creating OCAs [31]. If the country is relatively open, the flexible exchange rate will greatly influence the internal price level since this form of exchange rate responds to external forces of demand and supply. The more open an economy is, the more accessible to a fixed exchange rate it should be [31]. This is to suggest that foregoing an exchange rate does not entail a serious loss of policy independence for member countries in a monetary union that are very open to international trade. The nominal exchange rate will no longer be an important adjustment tool for very open countries, because changes in its nominal value are quickly followed by changes in domestic prices, leaving the real exchange rate unaffected. Therefore, countries in OCA will experience stable real exchange rate.

Product diversification was also suggested as a crucial criterion for OCA [32]. A well-diversified economy rarely encounters demand shocks because positive changes in other areas caused by diversification of the economy will be offset by negative changes in the affected area. Product diversification lowers the probability of asymmetric shocks and reduces their negative effects. Thus a fixed exchange rate regime which can be facilitated by dollarization is more advantageous for a well-diversified economic structure.

\section{Literature Review}

The U. S. dollar which has been Panama's legal tender for 114 years, and this "self-denying ordinance", [33] has given the country a degree of monetary stability. Dollarization in Panama has been observed to eliminate foreign exchange risks, currency mismatches, and speculative attacks so common in other countries with central banks and "sovereign" money [34]. The superb performance of inflation in Panama has been attributed to dollarization.

The dividends of dollarization have been sustained in Panama basically because of the stable value of the US dollar. The country has been severally described as one of the best performing countries in Latin America. In 2014, the misery index - an informal measure of the state of an economy generated by adding together its rate of inflation 
and its rate of unemployment - for Panama was the lowest with a value of 9.39 amongst 18 Latin American countries. In 2014, economic growth in Latin America and the Caribbean was a measly $0.8 \%$. Again, in 2014, her economic growth rate has been sustained at $6.2 \%$ unlike the average of $0.8 \%$ in Latin America and the Caribbean [35]. Panama's economy is considered to be among the fastest growing and best managed in Latin America.

As of 2012 Panama had an unemployment rate of $2.7 \%$. A food surplus was registered in August 2008. On the Human Development Index, Panama ranked 60th in 2015. The Latin Business Chronicle had predicted that Panama would be the fastest growing economy in Latin America during the five years period 2010-14, matching Brazil's 10\% rate [36].

Panama's relative performance was summarized in three points. First, Panama's experience confirms that an exchange rate peg, with dollarization being the extreme example, generates low and stable inflation. In this regard, it seems that the extreme pegs deliver even better inflation performance than do currency boards. Second, this gain in inflation performance is achieved without compromising average GDP growth, third, the absence of monetary financing did not preclude Panama from having large, persistent fiscal deficits that were no better than the typical Latin American country [37].

Ecuador embraced full dollarization in 2000 after the collapse of its financial system in 1998-1999 [17]. Following the financial banking crisis of 1999, the U.S. dollar became legal tender in Ecuador on March 13, 2000, and sucre notes (Ecuador's monetary unit) ceased being legal tender on September 11. Ecuador dollarized in 2000 in the midst of a severe economic crisis with a collapsing banking system, a sliding local currency, and after defaulting on its Brady bonds in late 1999 [16]. The regime was implemented in an attempt to reduce inflation, bring stability to the economy, and gain credibility with international investors. Since dollarization, Ecuador's inflation has been significantly reduced to single digits.

Reports of the effects of dollarization in Ecuador is mixed. While some praise dollarization for stabilizing the economy, others feel that the supporters and opponents of dollarization have overstated the policy's effects on the Ecuadorian economy. For instance, from 2015, thousands of Ecuadorians have crossed the bridge from Tulcán, Ecuador to the border town of Ipiales, Colombia to go shopping [38]. Ecuadorians purchase goods in Colombia en masse due to a simple fact: prices in Colombia have become significantly cheaper. The situation became a political concern such that the president issued a "call of conscience" to Ecuadorians, asking his compatriots to "offer support to the national production" by buying Ecuadorian products. Wang further noted that dollarization is not a sole remedy for all economic problems, neither is having a national currency.

El Salvador implemented its dollarization plan in 2001. This was followed by a fall in interest rate on consumer mortgage from 17 to 11 percent. However, El Salvador's economic growth since adopting the dollar as the official currency in 2001 has not performed any better [39]. It does appear as if El Salvador saw higher growth rates in the years prior to the adoption of the dollar though it is difficult to directly attribute the country's failure to obtain a higher growth rate solely to dollarization. For instance, it was observed that El Salvador's exports slowed because countries like China were trading with their own undervalued currency while El Salvador traded with the dollar which made El Salvador's exports relatively more expensive than Chinese exports.

The main driver of dollarization in many countries is the attempt by residents to protect the value of their wealth and income from being eroded by inflation and exchange rate depreciation [15]. For instance, in heavily dollarized economies, periods of sharp devaluations of the domestic currency are often met with a shift of financial assets and liabilities towards foreign currency, intensifying downward pressure on the exchange rate [40]. This would suggest that economies with higher inflation rates would have relatively high ratios of dollarization as savers shelter the real value of their wealth. Dollarization in Tanzania was found not to respond to inflation in a manner that is predicted by the literature [41].) Using the Chow test (Chow (1960) to see if the variables of the exchange rate volatility and inflation rate fluctuation contributed to dollarization in Tanzania, results were equally negative and insignificant [42]. Another study however found that the higher the domestic inflation rate visà-vis foreign inflation, the higher the level of foreign currency holdings [43]. Inflation was also found to increases as a result of an increase in dollarization suggesting a bidirectional association [44].

The effect of dollarization on the economy are mixed. While countries such as Panama are lauding its effects, dollarization was the first challenge and obstacle preventing Somaliland from achieving development and higher economic growth [45]. Dollarization may also complicate the process of setting monetary policy objectives [8]. Furthermore, dollarization brings many challenges that could have adverse effect on inflation targeting [46].

According to an IMF team, experience shows that dollarization is often difficult to reverse [47]. While the use of a foreign currency as a store of value or for domestic transactions has increased, there are very few cases in which the trend had been significantly reversed [48]. This difficulty may be attributed to the fact that many particularly in developing countries exercise more confidence in foreign currencies which are often more valuable than domestic currencies [49]. Practices regarding the use of currencies for the settlement of transactions change slowly and only when there are significant benefits to be gained from switching currencies [21].

Many SMEs hesitate to expanding into international markets because of the variation in national business environments which often times require the conversion of currencies [50]. In addition to the political and economic factors which influence currency exchange, investors also have to consider whether the country in which they are 
investing has a stable currency. Dollarization has been identified as a viable solution to this problem because it reduces the currency risk and makes it easier for businesses to expand outside of their home markets. However, while investigating Capital structure decisions in a highly dollarized economy, it was established that firms with higher returns on assets, and thus stronger capacity to generate internal funds, are more sensitive to currency mismatch risks in relying on US dollar borrowing than firms with lower returns on assets in Cambodian firms [51].

In relation to international trade, dollarization was noted to increase bilateral trade with dollarized countries, while also promoting a bilateral trade within the country that dollarized and other dollar-zone countries as well [52]. Their study reevaluated the average treatment effect of dollarization on bilateral US trade with the six dollarized countries and on bilateral trade of the dollarized countries and carefully controlled for non-random selection of policy adoption. They found strong and robust evidence that dollarization not only significantly increases bilateral US trade with dollarized countries, but promotes trade among dollar-zone countries as well. Their results suggested that the trade-enhancing effects of dollarization are substantial.

In Nigeria, studies have investigated the relationship between nominal exchange rate volatility and dollarization in Nigeria using the Granger causality test from 1986 to 2003 [13]. Results from the study revealed a bi-directional relationship between exchange rate volatility and dollarization, though the causality was stringer from dollarization to exchange rate volatility [53]. The study recommended that policies aiming to reduce exchange rate volatility in Nigeria must include measures that specifically address the issue of dollarization in the country.

Another study investigated the existence and extent of currency substitution and also examined the impact of same on the demand for money in Nigeria from 1980-2014. The study estimated six models based on Cuddington's currency substitution framework [53]. Findings revealed that currency substitution has increased over time in Nigeria and the determinants of currency substitution were expected rate of depreciation, inflation rate, election period, and crude oil price as well as foreign rate of interest. Additionally, activities such ceiling on the interest rate for US dollar deposits and the interest rate differentials have also been identified as important factors affecting deposit dollarization [54].

The performance of Nigeria's macro economy since its independence has not been commendable though the country has the potential of being a force to be reckoned with considering its abundant human and natural resources. The country has over the years struggled with poor macroeconomic performance. Recently, it was reported that Nigeria has overtaken India as world's poverty capital with 87 million Nigerians living in extreme poverty [55]. Most government policies to address these poor performing macrovariables have proved unsuccessful over the year and the Nigerian government may need to rethink its policy stance to address the hardship wrecking Nigerians.

The country has been struggling with persistent inflationary pressures over the years. Beginning from 1969 with the Nigerian civil war, and in the 70 s following government's effort to reconstruct the war-damaged country, inflation rate in Nigeria has persistently remained very high, peaking in 1995 at $72.8 \%$ [56]. Government's effort to achieve single digit inflation over the years with different monetary policy regimes has been unsuccessful as the trend is hardly sustained for more than two years. Compared to a dollarized economy like Panama, Nigeria's instability calls for pragmatic actions on the part of policy makers as evident in figure 1.

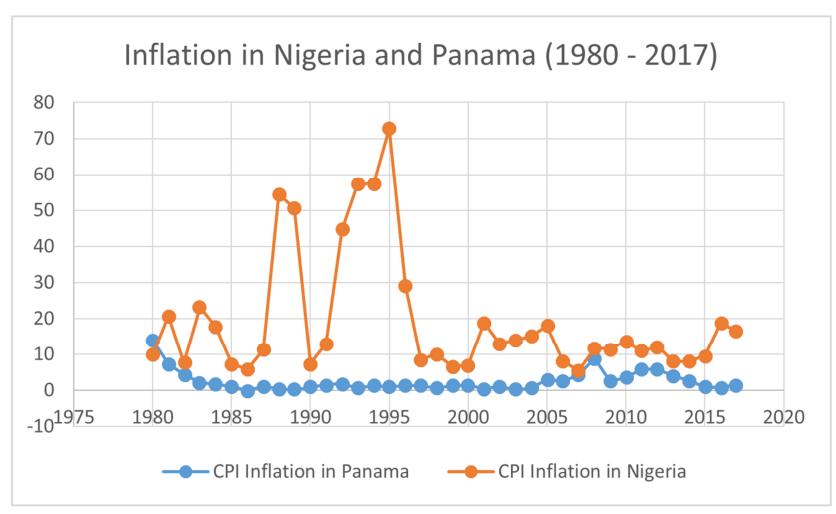

Source: IMF: World Economic Outlook (WEO) Database, October 2018

Figure 1. Inflation in Nigeria and Panama (1980-2017).

According to data [57], in 2017, real GDP growth in Nigeria was $0.8 \%$ placing Nigeria in the $164^{\text {th }}$ position out of 190 countries. Pathetically, when compared to Libya with the highest growth rate of $64 \%$ in 2017 , Nigeria had $98.74 \%$ lower real GDP growth. In terms of per capita GDP, Nigeria has one of the lowest and it has been on the decline. Compared to that of Equatorial Guinea's \$34,865-the richest country in Africa, Nigeria's pathetic situation becomes all the more obvious [58]. Again compared to Panama, with identical population growth rate, Nigeria is crawling as a nation.

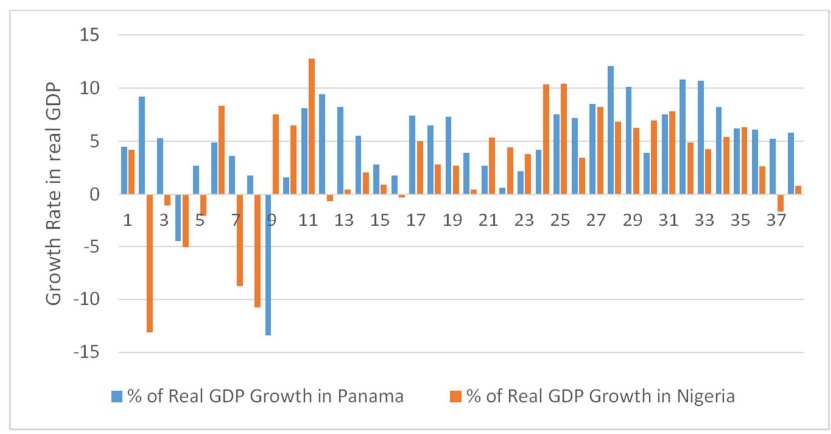

Source: IMF: World Economic Outlook (WEO) Database, October 2018

Figure 2. Growth rate of Real GDP in Nigeria and Panama.

In 2010, when the Vision 20:2020 was enacted, it was projected that for Nigeria to be amongst the 20 most 
industrialised economies in the world by 2020, her GDP must grow at an annual rate of $14 \%$. The highest growth rate recorded for the country since then has been $7.84 \%$ an indication that the country is very far from realising her vision.

Table 1. Growth rate in GDP and Real GDP for Nigeria (2010-2017).

\begin{tabular}{lll}
\hline Year & Growth Rate in GDP & Growth rate in Real GDP \\
\hline 2010 & 4.89 & 7.84 \\
2011 & 4.28 & 4.89 \\
2012 & 5.39 & 4.28 \\
2013 & 6.31 & 5.39 \\
2014 & 2.65 & 6.31 \\
2015 & -1.62 & 2.65 \\
2016 & 0.81 & -1.62 \\
2017 & -100.00 & 0.81 \\
\hline
\end{tabular}

Source: World Economic Outlook Database, 2018

Nigeria's per capita GDP has remained one of the lowest globally. This indicator which serves as a measure of a country's living standards makes comparison of the prosperity level of countries with different population sizes possible. While the countries with the highest GDP per person often have prosperous economies and few residents, the study by United Nations Development Program in 2007 revealed that some countries have had relatively rapid population growth alongside a rapid increase in per capita GDP [59]. Nigeria and Panama have relatively identical population growth rate but very diverse PCI as shown in figure 3 .

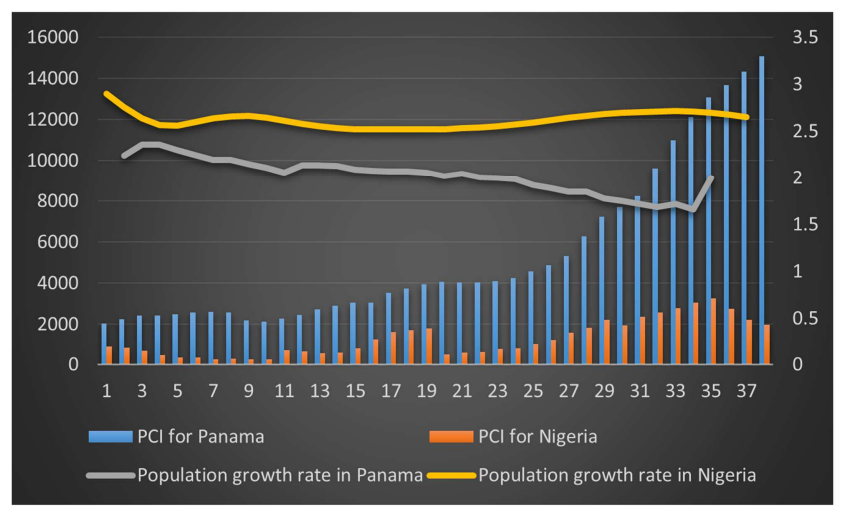

Figure 3. PCI and Population Growth rate for Nigeria and Panama.

Using the Solow model, it was explained that higher levels of savings and investment contributes to higher level of PCI [60]. Nigerians have a poor saving culture. Coupled with the high level of poverty in the country, the low PCI is only but a reflection of the prevailing macroeconomic conditions in Nigeria.

Unemployment has remained a bane particularly among the youths in Nigeria. The Labour Statistics report of Nigeria in Q4 2017 revealed that 7.9 million youths between the ages of 15-34 were unemployed while the National Bureau of Statistics reported $61.6 \%$ rate of youth employment as at June 5, 2017. Comparatively, unemployment rate is much higher in Nigeria than in Panama a dollarized economy as evident from figure 4.

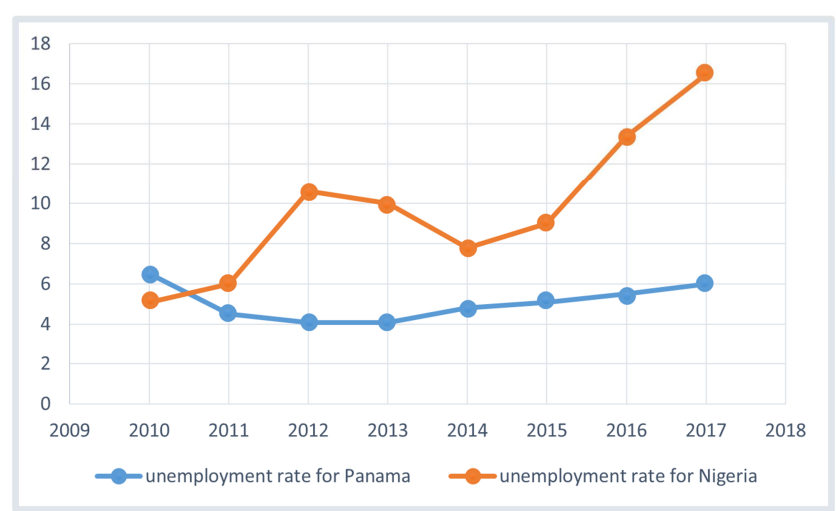

Source: IMF: World Economic Outlook (WEO) Database, October 2018

Figure 4. Unemployment Rate in Nigeria and Panama (2010-2017).

In relation to the strength of its currency, the purchasing power of the naira as reflected by the values of its real effective exchange rate (REER) reveals a weak currency whose purchasing power is consistently declining. This indicator which compares a country's currency to a basket of other countries' currencies is often used to compare a domestic currency's performance to the country's most important trade partners. This is illustrated in figure 5.

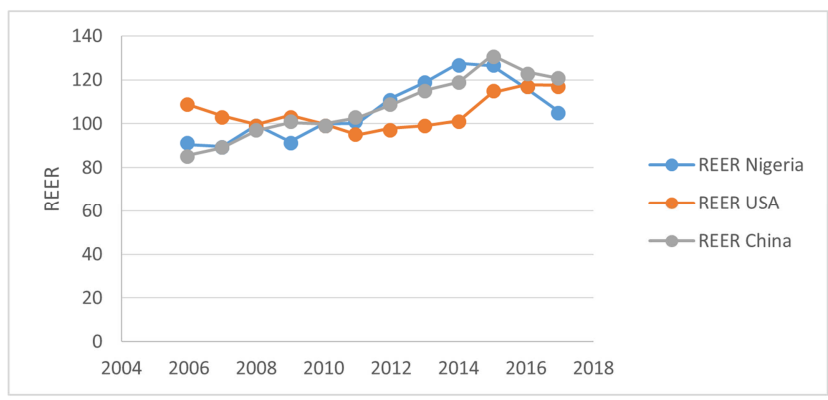

Source: World Development Indicators (October, 2018); bridgat.com

Figure 5. Movement in REER in Nigeria, USA and China.

In figure 5, the REER for Nigeria was compared with two of its prominent trading partners-China and the United States of America. Though the indicator is relatively identical for the three countries, Nigeria's REER began a rather steep decline in 2014 compared to China and the USA whose marginal decline began a year later in 2015. This indicates a deeper weakening of the naira compared to the yuan and dollar.

Given the dismal performance of most of the macroeconomic indicators in Nigeria, it is evident that the country needs a viable means of intervention to drive economic progress. Dollarization is increasingly being considered a viable economic tool that can help economies like Nigeria achieve stability, growth, and prosperity while increasing some level of credibility in governance. The experience of Panama might be repeated in Nigeria with full dollarization of the economy. It has been suggested that vulnerable emerging-market countries can always do away 
with their central banks and domestic currencies, replacing them with a sound foreign currency to enjoy the benefits associated with the strong currencies [35].

\section{Methodology and Sources of Data}

\subsection{Methods}

There are different ways of measuring dollarization in an economy, and deposit dollarization is one way. Deposit dollarization is when economic agents seek to conserve the value of their wealth in foreign assets such that they switching from holding domestic currency into holding foreign currencies in bank accounts domiciled in domestic banks [21]. Options have been proposed to construct a dollarization index which measures the extent of a country's reliance on foreign currency [61-62]. In this study we adopt the relationship proposed in an International Monetary Fund (IMF) working paper [63]. Since foreign currency deposits (FCDs) are in different foreign currencies, exchange rate movements could lead to big swings in the dollarization ratio even with constant stock of FCDs in foreign currency terms. Thus, foreign exchange holdings need to be adjusted for exchange rate changes to prevent an exchange-rate bias. Therefore, they proposed the generation of a "real" deposit dollarization index by converting both foreign currency deposits and bank deposits to dollars and multiplying both (back to domestic currency) by a fixed base-year nominal exchange rate. The "real" deposit dollarization indicator is thus derived as a constant-exchange rate indicator as shown.

$$
D_{i}=\frac{a F C D_{t}}{a F C D_{t}+L C D_{t}}
$$

$a F C D$ is adjusted foreign currency deposit and it is derived by the relationship below.

$$
\frac{F C D_{t}}{N E R_{t} * N E R_{2010}}
$$

Where NER is nominal exchange rate (local currency per dollar). NER for Year 2010 is used as a fixed base-year NER for the adjustment since 2010 is currently the base year in Nigeria. The index computed is used as the explanatory variable in the study to examine its impact on selected macroeconomic variables in Nigeria using simple regression analysis to summarize and reveal the existing relationship between dollarization and macroeconomic variables in Nigeria.

\subsubsection{Model Specification}

The simple linear regression model for the study is thus specified as

$$
Y=f(X)
$$

Where:

$\mathrm{X}$ represents the independent variables

$X=$ Dollarization index $(D i)$
$Y$ represents the dependent variables defined as

$Y_{1}=$ Foreign Direct Investment $(F D I)$

$Y_{2}=$ Growth rate in Real GDP growth rate $(\mathrm{GRGDP})$

$Y_{3}=$ Inflation Rate $(I N F L R)$

$Y_{4}=$ Per Capita Income $(P C I)$

$Y_{5}=$ Prime Lending Rate $(P L R)$

$Y_{6}=$ Total Trade $($ TTRD)

$Y_{7}=$ Unemployment Rate (UNER)

Since there are seven responses with the same predictor, each response will follow its own regression model as specified

$$
\begin{aligned}
& Y_{1}=\alpha_{1}+\beta_{1} X+\varepsilon_{1} \\
& Y_{2}=\alpha_{2}+\beta_{2} X+\varepsilon_{2} \\
& Y_{3}=\alpha_{3}+\beta_{3} X+\varepsilon_{3} \\
& Y_{4}=\alpha_{4}+\beta_{4} X+\varepsilon_{4} \\
& Y_{5}=\alpha_{5}+\beta_{5} X+\varepsilon_{5} \\
& Y_{6}=\alpha_{6}+\beta_{6} X+\varepsilon_{6} \\
& Y_{7}=\alpha_{7}+\beta_{7} X+\varepsilon_{7}
\end{aligned}
$$

The apriori expectations are: $\beta_{11}>0 ; \beta_{12}>0 ; \beta_{13}<0 ; \beta_{14}>$ $0 ; \beta_{15}<0 ; \beta_{16}>0 ; \beta_{17}<0$

Where: $\varepsilon$ is the error associated with different responses and $\left(\varepsilon_{1}, \varepsilon_{2}, \varepsilon_{3}, \varepsilon_{4}, \varepsilon_{5}, \varepsilon_{6}, \varepsilon_{7}\right)$ has expectation $0 . \beta_{0}$ is the intercept and $\beta_{11}$ to $B_{16}$ are unknown and fixed) regression coefficients.

\subsubsection{Sources of Data}

Data for the study were sourced from Central Bank of Nigeria Statistical Bulletin and the World Economic Outlook Database (WEO). The study covers a period of 46 years, from 1972 to 2017.

\subsection{Results and Discussions}

Trend analysis of the data was performed to trace the behaviour of the variables overtime and to explain the nature of the data.

From figure 6, FDI into the country was rather insignificant in Nigeria until 1998. Since then, the country rapid growth in FDI until 2009 when it dropped suddenly and picked up again suddenly in 2011 after which it began a gradual descent before picking up again in 2015. The growth rate in real GDP on the other hand reveals no trend but consistent fluctuation with its lowest value recorded in 1981 and highest value in 1990. Inflation rate in the country reveals series of fluctuations, peaking in 1994 and its lowest in 1972. The Per capita income on the other hand reveals a downward trend from 1972, recording its lowest value of $173,001.90$ in 1987 after which it started increasing, peaking at 385,227 in 2014 after which it started falling again. The prime lending rate initially increased and peaked at a value of 29.80 in 1992 after which it became relatively stable with an average value of 18.00 except in 1997 when it dropped to a record low of 13.54 and 2002 when it increased to 24.85 . The dollarization index shows a steep increase from 1977, 
reaching its highest value in 1983. The index however dropped sharply thereafter and has been relatively stable over the last 27 years. Real FCD on the other hand increased sharply from 2007 and peaked in 2014 the same year the PCI was at its highest. Thereafter, RFCD has been on a downward trend. Total trade in Nigeria reveals a positive trend same

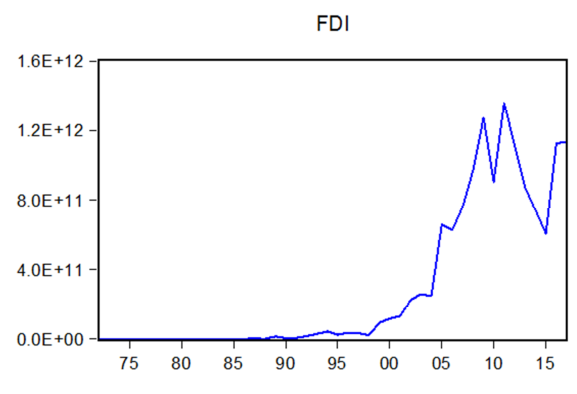

$\mathrm{PCI}$

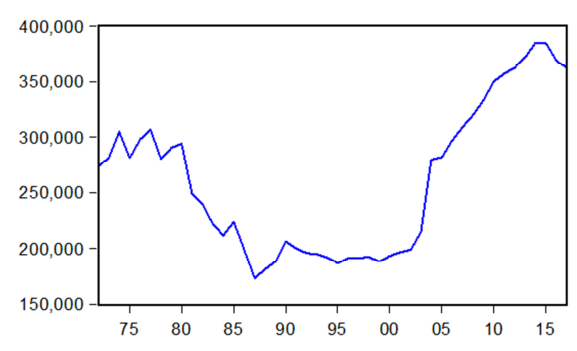

RFCD

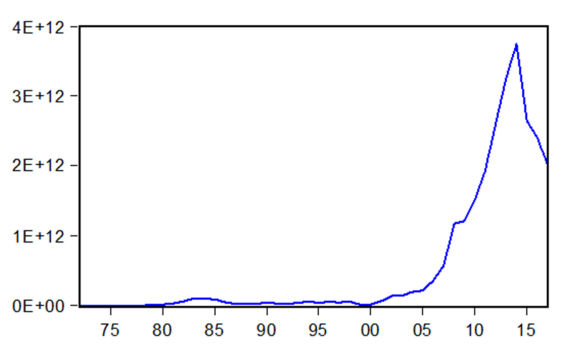

with unemployment rate which record its highest value of 23.9 percent in 2011. The rate however dropped to 7.8 percent in 2014, tallying with the year both PCI and RFCD where highest. After 2014, unemployment has been on the increase in Nigeria.
GRGDP

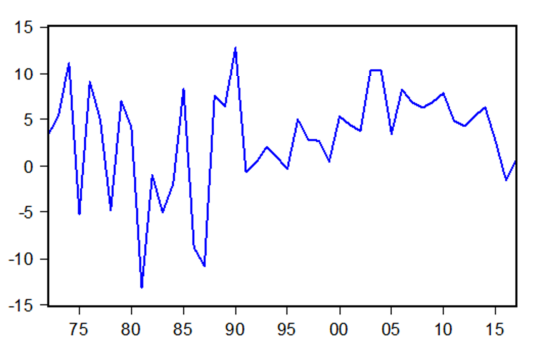

PLR

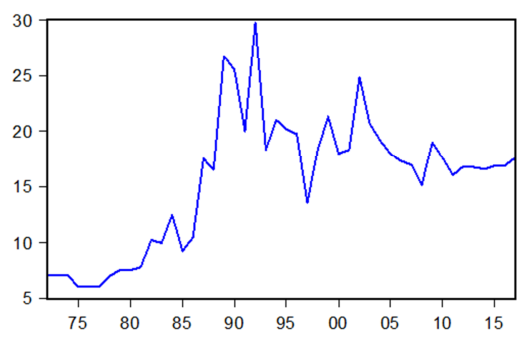

TTRD

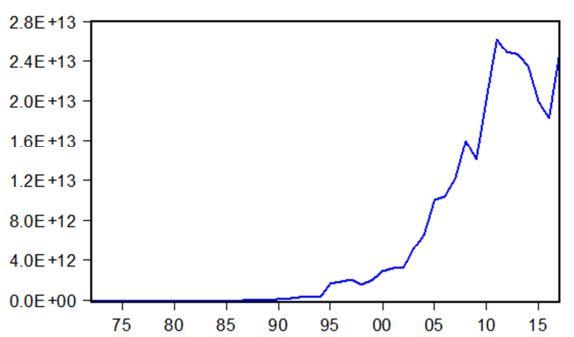

INFLR

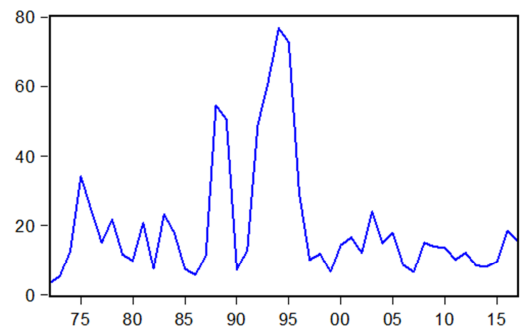

RDI

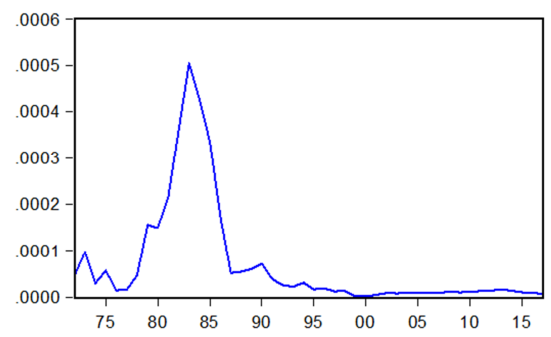

UNER

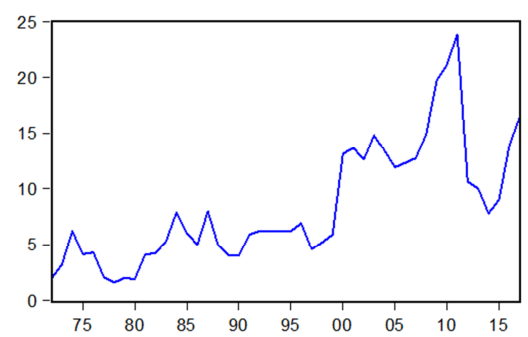

Figure 6. Trend in Variables of Interest.

\subsubsection{Unit Root Test}

The presence of unit root has significant implications for econometric modelling. It produces spurious regressions where what appears to be a significant coefficient is frequently really not at all significant. It could also produce high r-squared values even if the data is uncorrelated. To avoid this, the unit root test was conducted to determine the order of integration of the variables. The results are presented in Table 2.

Table 2. Unit Root Test.

\begin{tabular}{|c|c|c|c|c|c|c|c|}
\hline \multirow{2}{*}{ Variables } & \multicolumn{3}{|l|}{ Levels } & \multicolumn{3}{|l|}{ First Difference } & \multirow{2}{*}{$\begin{array}{l}\text { Order of } \\
\text { Integration }\end{array}$} \\
\hline & ADF Test Statistic & Critical Value & P Value & ADF Test Statistic & Critical Value & P Value & \\
\hline LOGFDI & 4.458 & -2.9297 & 0.8919 & -10.3181 & -2.9297 & 0.0000 & $\mathrm{I}(1)$ \\
\hline GRGDP & -5.7018 & -2.9281 & 0.0000 & - & - & - & $\mathrm{I}(0)$ \\
\hline INFLR & -3.9566 & -2.9297 & 0.0037 & - & - & - & $\mathrm{I}(0)$ \\
\hline LOGPCI & -0.3462 & -2.9281 & 0.9094 & -5.5074 & -2.9297 & 0.0000 & $\mathrm{I}(1)$ \\
\hline PLR & -1.7489 & -2.9297 & 0.4003 & -10.5301 & -2.9297 & 0.0000 & $\mathrm{I}(1)$ \\
\hline LOGTTRD & -1.3083 & -2.9281 & 0.6177 & -6.9053 & -2.9297 & 0.0000 & $\mathrm{I}(1)$ \\
\hline UNE R & -1.7460 & -2.9281 & 0.4019 & -6.4892 & -2.9297 & 0.0000 & $\mathrm{I}(1)$ \\
\hline
\end{tabular}

From Table 2, the Augmented Dickey Fuller Test reveals that only two of the eight variables are stationary at level while the others are stationary at first difference. Therefore, to run our regression, the values of GRGDP and INFLR will be used at levels while the differenced values will be used for the remaining six variables. 


\subsubsection{Descriptive Statistics}

To describe the basic features of the data employed in the study, we performed descriptive statistics and these are presented in table 3 .

Table 3. Descriptive Statistics.

\begin{tabular}{llllllll}
\hline & DLOGFDI & GRGDP & INFLR & DLOGPCI & DPLR & DRDI & DLOGTTRD \\
\hline Mean & 0.1919 & 3.0229 & 20.2672 & 0.0062 & 0.2351 & $-8.94 \mathrm{E}-07$ & 0.2052 \\
Median & 0.1369 & 4.2793 & 13.9296 & 0.0151 & 0 & $3.39 \mathrm{E}-07$ & 0.1439 \\
Maximum & 2.0878 & 12.766 & 76.7589 & 0.2651 & 10.3 & 0.0001 & 1.5314 \\
Minimum & -1.0764 & -13.1279 & 5.4 & -0.1679 & -11.48 & -0.0002 & -0.2726 \\
Std. Dev. & 0.6366 & 5.664 & 17.6461 & 0.0685 & 3.7471 & 0.0001 & 0.3414 \\
Skewness & 0.9833 & -0.9034 & 1.9098 & 0.4654 & 0.1681 & 0.0783 & 1.7495 \\
Kurtosis & 4.4484 & 3.6582 & 5.7409 & 6.8067 & 5.3511 & 5.8927 & 7.385 \\
\hline
\end{tabular}

From table 2, since the values of the mean and median are not too wide in all cases, it means none of the data set has obvious outliers. Also the difference between the minimum and maximum values reveals the variability or the spread of data and we can deduce that the data set are widely spread out and not clustered together. The descriptive statistics reveal that none of the data are perfectly symmetrical which must have skewness value of zero. However, $D R D I$ is almost symmetrical with a value of 0.78. DLOGPCI and DPLR are fairly symmetrical with values between -0.5 and 0.5 . DLOG $F D I$ and $G R G D P$ on the other hand are moderately skewed while INFLR and DLOGTTRD are highly skewed and positively while DUNER is highly but negatively skewed. The value of kurtosis for all the variables shows that the variables all have heavy tails thus they are all leptokurtic.

\subsubsection{Results of Regression Analysis}

After fitting the models, we checked the residual plots to be sure our estimates were unbiased (see appendix for the residual plots). Since the plots were all randomly dispersed or with a random pattern around the horizontal axis, our linear regression model was considered appropriate. The regression analyses were performed to determine how changes in the independent variables are associated with changes in the dependent variable. The estimated equations are shown below. The estimated linear equations are shown below.

$$
\begin{gathered}
D L O G F D I=0.1901-1993.866 D R D I+\varepsilon_{1} \\
G R G D P=3.0253+2622.511 D R D I+\varepsilon_{4}
\end{gathered}
$$

$$
\begin{gathered}
I N F L R=20.2839-18735.93 D R D I+\varepsilon_{3} \\
D L O G P C I=0.0063+28.0459 R D I+\varepsilon_{2} \\
D P L R=0.2325-2908.290 D R D I+\varepsilon_{5} \\
D L O G T T R D=0.2037-1680.518 D R D I+\varepsilon_{2} \\
D U N E R=0.3209-1456.895 D R D I+\varepsilon_{5}
\end{gathered}
$$

To determine whether the coefficients of our independent variables are really different from 0 and that our independent variable $(R D I)$ has genuine effect on the dependent variables we consider the individual standard errors and $\rho$-values from the regression output. If a coefficient is large compared to its standard error (SE), then it is probably different from 0 and if it is, then the $\rho$-value will be 0.05 or less indicating that the coefficients are statistically significant. Thus lower values of SE are preferred.

The goodness of fit for each of the model is expectedly measured using the R-squared which indicates the percentage of the variance in the dependent variable that the independent variable $(R D I)$ explains. However, before relying on the value of the R-squared, we examined the residual plots to ensure that the models were not biased. The F-statistic is used to determine the overall significance of the model. If the p-value for the F-statistic is less than 0.05 then we will conclude that our regression model fits the data better than the model with no independent variables otherwise, we will conclude that the R-squared is equal to zero.

Table 4. Regression Results.

\begin{tabular}{llllllll}
\hline Regressands & DLOGFDI & GRGDP & INFLR & DLOGPCI & DPLR & DLOGTTRD & DUNER \\
\hline Variables & Statistics & & & & & & \\
\hline
\end{tabular}

Note: ()-standard errors

[]- $\rho$-values

** Significant at 10 percent

From Table 4, the coefficient of RDI for FDI is negative meaning that as RDI increased, FDI will fall. This was 
against our expectation. The result is however not statistically significant as reflected by the p-value. The value of the R2 reveals that only 2.81 percent of the variations in $F D I$ is caused by changes in the $R D I$. This result is however not useful as the F-statistic reveals that the model for FDI is not statistically significant thus the value of the $\mathrm{R}^{2}$ generated is not different from zero. Also the GRGDP which was supposed to respond positively to changes in $R D I$ has a negative coefficient. The values of the SE and $\mathrm{p}$ also reveals that $R D I$ is statistically insignificant in explaining changes in $G R G D P$. The explanatory power of the model (0.06 percent) is also very weak and statistically insignificant with a fstatistic of 0.0264 and p-value of 0.8718

Counterintuitively, results revealed that an increase in $R D I$ led to a fall in both INFLR and TTRD. These results are completely against findings by others. This means that if Nigeria becomes officially dollarized, then the government might not achieve its goal of lowering not increasing volume of trade in Nigeria. However, the result for INFLR is not statistically significant thus there is no evidence to show that the coefficient is statistically different form zero though statistical significance is established for TTRD at 10 percent. Further evidence reveal that the two models are very weak and statistically insignificant in explaining changes in both INFLR and TTRD in Nigeria as revealed by the respective values of $\mathrm{R}^{2}$ and F-statistics and the accompanying p-values.

The PLR, PCI and UNER all had the expected signs. For $P L R$ and $U N E R$, an increase in RDI will lead to a fall in prime lending rate and unemployment in Nigeria while it will lead to an increase in PCI. However, RDI was not found to be statistically significant in explaining changes in these variables neither did the models exhibit strong explanatory power nor statistical significance to show that they are not different from models with no independent variables. The $\mathrm{R}^{2}$ values for PLR, PCI and UNER were 0.05 percent, 0.17 percent and 0.07 percent respectively. The p-values associated with the f-statistic were all greater than 0.05 and even 0.10 .

\section{Conclusion and Recommendation}

The basic objective of this study was to examine the impact of dollarization on selected macroeconomic variables in Nigeria. The basic motivation for this study the suggestion in literature that countries that dollarize tend to enjoy low inflation rates. Besides the consensus on the effect of dollarization on inflation, its effects on economic variables such as growth in real output, unemployment rate and income levels are sometimes believed to be beneficial as the case in Panama (Hanke, 2017). Therefore, the a-priori expectations were that RDI will have negative influence on PLR, UNER, and INFLR while it will have a positive influence on $F D I$, GRGDP, PCI and TTRD.

The, a priori expectation was met for three variables $P L R$, $P C I$ and UNER but not for GRGDP, INFLR, PCI and TTRD. Meaning that dollarization of the Nigerian economy will have mixed effects. However, at here was no evidence to show from the study that the coefficients generated were statistically different from zero based on the p-vales generated. Again, in addition to the very weak $\mathrm{R}^{2}$ values generated in all the models, the f-statistic associated with each of the models also revealed that none of the models were statistically significant. These results are indication that the experience of Panama due to dollarization may not be repeated in Nigeria.

The study therefore recommends that government should be intentional about discouraging dollarization in Nigeria since it is not a major determinant of the performance of macroeconomic variables in the country. Also measures must be put in place to strengthen the Nigerian naira and to fight inflation so that Nigerians will not see the need to hold their wealth or transact with a foreign currency.

\section{References}

[1] Nigerian Bureau of Statistics. (2018) Nigeria GDP Annual Growth Rate. available at https://www.nigerianstat.gov.ng/

[2] Klein, M. W. (2002). Dollarization and Trade. National Bureau of Economic Research (NBER) Working Paper No. 8879. Available at http://www.nber.org/papers/w8879

[3] Mengesha, L. (2014). The How, Why and What questions of Dollarization. The Empirical Economics Letters, 13 (7), 1-15.

[4] Musoke, Z. (2017). An Empirical Investigation on Dollarization and Currency Devaluation: A Case Study of Tanzania. Economics. Discussion paper No. 2017-8 available at $\quad \mathrm{http}: / / \mathrm{www} . e c o n o m i c s-$ ejournal.org/economics/discussionpapers/2017-8

[5] Levy-Yeyeti, E. \& Sturzenegger, F. (2001). To Float or to Trail: Evidence on the Impact of Exchange Rate Regimes. Universidad Torcuato di Tella.

[6] Rose, A. (2000). One Money, One Market: The Effect of Common Currencies on Trade. Economic Policy: A European Forum. 30, 7-33.

[7] Rose, A. \& van Wincoop, E. (2001). National Money as a Barrier to International Trade: The Real Case for Currency Union. American Economic Review. 91 (2), 386-390.

[8] Fabris, N \& Vujanović, N. (2017). The Impact of Financial Dollarization on Inflation Targeting: Empirical Evidence from Serbia. Journal of Central Banking Theory and Practice, 2, 23-43.

[9] Olayungbo, D. O \& Ajuwon, K. T. (2015). Dollarization, Inflation and Interest Rate in Nigeria. CBN Journal of Applied Statistics. 6 (1), 241-261.

[10] Omoh, G. (December 2, 2012). Dollarisation of the Nigerian Economy: Who is to blame? Vanguard. Available at https://www.vanguardngr.com/2012/12/dollarisation-of-thenigerian- economy-who-is-to-blame-2/

[11] Obianwu, C. (2015). CBN Clarifies Currency Substitution and Dollarization of the Nigerian Economy. Retrieved https://www.templars-law.com/wpcontent/uploads/2015/08/CBN-clarifies-CurrencySubstitution-and-Dollarisation-Chike-Obianwu.pdf 
[12] The Nation Newspaper (March 14, 2017). Reps to Probe Schools Collecting Fees in Foreign Currency. Retrieved from $\mathrm{http}: / /$ thenationonlineng.net/reps-probe-schools-collectingfees-foreign- currency/

[13] Yinusa, O. (2008). Between dollarization and exchange rate volatility: Nigeria's Portfolio Diversification Option. Journal of Policy Modeling, 30 (5), 811-826.

[14] Nor, M. I. (2012). The Effect of Dollarization on Developing Economies: Lessons from Somalia's Informal Market. Academic Research International. 2 (3), 591-597.

[15] Honohan, P. (2007). Dollarization and Exchange Rate Fluctuations. World Bank Policy Research Working Paper 4172

[16] Arellano, C. \& Heathcote, J. (2007). Dollarization and Financial Integration. Social Science Research Network. International Finance Discussion Papers Number 890.

[17] Gale, D. \& Vives, X. (2001). Dollarization, Bailouts and the Stability of the System. London School of Economics. Retrieved from https://blog.iese.edu/xvives/files/2011/06/45Dollorization1.pdf

[18] Calvo, G. A. \& Vegh, C. A. (1992). Currency Substitution in Developing Economies: An Introduction. International Monetary Fund Working Paper No. 92/40: 73-95.

[19] Effiom, L. \& Samuel, U. P. (2010). The Currency Substitution Phenomenon: Is the Nigerian Economy Immune? Journal of Economic Theory. 1 (4), 9-13.

[20] Feige, E. L. \& Dean, J. W. (2002). Dollarization and Euroization in Transition Countries: Currency Substitution, Asset Substitution, Network Externalities and Irreversibility. Paper presented at the Fordham University International Conference on "Euro and Dollarization: Forms of Monetary Union in Integrating Regions" April 5 - 6, 2002, New York.

[21] Balino, T. J., Adam B., \& Eduardo B. (1999). Monetary Policy in Dollarized Economies. Occasional Paper 171. Washington: International Monetary Fund.

[22] Encinas-Ferrer, C. (2015). The ABC of Dollarization. Universidad del Valle de Atemajac Plantel León. Retrieved from https://www.researchgate.net/publication/282176539

[23] Schuler, K. (2000). Basics of Dolarization. Retrieved on Friday 09, $2016 \quad$ from https://www.globalpolicy.org/pmscs/30435.html?tmpl=compo nent\&print $=1 \&$ page

[24] Musse, O. S. H \& Echchabi, A. (2017). Dollarization in East Africa: Causes, Consequences, and Future Forecasts. Binus Business Review, 8 (1), 15-22.

[25] Levy-Yeyati, E \& Sturzenegger, F. (2001). Dollarization: A Primer. Introductory Chapter to Dollarization, edited by LevyYeyati, E and Sturzenegger, F. MIT Press.

[26] Bogeti, Z. (1999) Official or "Full" Dollarization: Current Experiences and Issues. International Monetary Fund. Retrieved on Tuesday December 13, 2016 from http://www.geocities.ws/mugajava.geo/edisi04/bogdllr.htm

[27] Tasseven O. (2017) The Link Between Dollarization and Its Determinants in Turkey. In: Dinçer H., Hacioğlu Ü. (eds) Risk Management, Strategic Thinking and Leadership in the Financial Services Industry. Contributions to Management Science. Springer.
[28] Odajima K. (2017) Dollarization in Cambodia: Behavior of Households and Enterprises in a Highly Dollarized Environment. In: Kubo K. (eds) Dollarization and Dedollarization in Transitional Economies of Southeast Asia. IDE-JETRO Series. Palgrave Macmillan.

[29] Mundel, R. A. (1961). A Theory of Optimum Currency Areas. The American Economic Review, 51 (4), 657-665.

[30] Alesina, A. and Barro, R. J. (2001). Dollarization. American Economic Association (AEA) Papers and Proceedings 91 (2), 381-385.

[31] Mckinnon, R. I. (2004). Optimum Currency Areas and Key Currencies: Mundell I versus Mundell II* Journal of Common Market Studies. 42 (4), 689-715.

[32] Kenen, P. B. (1969), The Theory of Optimum Currency Areas: An Eclectic View, in R. A. Mundell and A. K. Swoboda, (eds.), Monetary Problems of the International Economy. University of Chicago Press: Chicago.

[33] Moreno-Villalaz, J. L. (2005). Financial Integration and Dollarization: The Case of Panama. Cato Journal. 25 (1), 127140.

[34] Goldfajn, I., Olivares, G., Jeffrey, F., \& Milesi-Ferretti, G. M. (2001). Full Dollarization: The Case of Panama. Economia. 1 (2), 101-155.

[35] Hanke, S. H. (2017). Follow Panama: Dollarize. Retrieved from https://www.huffpost.com/entry/follow-panamadollarize_b_7444282

[36] Exportimportstatistics.com. (n.d). Panama. Available at http://www.exportimportstatistics.com/countryprofile/Panama-profile.aspx

[37] Goldfajn, I. \& Olivares, G. (2001). Full Dollarization: The Case of Panama. Economia 1 (2); 101- 155.

[38] Wang, S (2016). Examining the Effects of Dollarization on Ecuador. Council on Hemisphere Affairs.

[39] Voices on the Border (2011). Ten Years Later- The Impact of Dollarization in El Salvador. Information and Analysis from El Salvador. Available at https://voiceselsalvador.wordpress.com/2011/06/08/ten-yearslater-the-impact-of-dollarization-in el-salvador/

[40] Isaac, M \& Ike, M. (2016). Financial Sector Development and Dollarization in Emerging Economies. International Review of Financial Analysis. 46; 20-32.

[41] Kessy, P. (2011). Dollarization in Tanzania: Empirical Evidence and Cross Country Experience. International Growth Centre London School of Economics.

[42] Agwambo, N. J. (2013). A Comparative Analysis of Dollarization in Tanzania and Argentina. A research report submitted to the Faculty of Commerce, Law and Management, University of the Witwatersrand, Johannesburg, in fulfilment of the requirements for the degree of Masters of Management in Finance and Investment (MMFI).

[43] Bogetic, Z. (2000). Official dollarization: Current experiences and issues. Cato Journal, 20 (2), 179-213.

[44] Mengesha, L. G. \& Holmes, M. J. (2015). Does Dollarization Reduce or Produce Inflation? Journal of Economic Studies, 42 (3); 358-376. 
[45] Mohamad, A. M \& Mohamoud, M. O. (2016). The Effect of Dollarization on Economic Growth: The Case of Selected Financial Institutions in Hargeisa District, Somaliland. Thesis submitted to the department of Economics of Admas University, Hargeisa, Somaliland.

[46] Fabris, N. \& Galić, J. (2016). Ciljanje inflacije u zemljama sa dvovalutnim režimima. Meeting of Scientific Association of Economists, December. Belgrade: Scientific Association of Economists.

[47] Mecagni, M., Corrales, J. S., Dridi, J., Garcia-Verdu, R., Imam, P., Matz, J., Macario, C., Maino, R.,..., Yehoue, E. (2015). Dollarization in Sub-Saharan Africa Experience and Lessons. International Monetary Fund Publication.

[48] Kubo K. (2017) Dollarization and De-dollarization in Transitional Economies of Southeast Asia: An Overview. In: Kubo K. (eds) Dollarization and De-dollarization in Transitional Economies of Southeast Asia. IDE-JETRO Series. Palgrave Macmillan.

[49] Mundaca, G. (2018). Central Bank Interventions in a Dollarized Economy: Managed Floating versus Inflation Targeting. Japanese journal of Statistics and Data Science. 55 (4); 1507-1535.

[50] Harper, B. S., Harper, P. \& Coronel, C. (2002). Dollarization: Making International Trade Seamless. The CPA Journal. 72 (1).

[51] Okudaa, H. \& Aibab, D. (2018). Capital Structure Decisions in a Highly Dollarized Economy: Evidence from Cambodian Firms. Journal of Asian Economics. 58; 1-18.

[52] Lin, S. \& Ye, H. (2007). Dollarization Does Promote Trade. Journal of International Money and Finance. 29 (6), 2010.

[53] Adamu, M. B. (2016). Currency Substitution and The Demand for Money in Nigeria: 1980-2014. Unpublished Project Thesis Submitted to The School of Postgraduate Studies, Ahmadu Bello University, Zaria.
[54] Anh, P. T. H. (2018). Zero Interest Rate for the US Dollar Deposit and Dollarization: The Case of Vietnam. In: Anh, L., Dong, L., Kreinovich, V. \& Thach, N. (eds) Econometrics for Financial Applications. ECONVN 2018. Studies in Computational Intelligence, 760. Spring.

[55] Akinkuotu, E. (June 26, 2018) With $87 \mathrm{~m}$ Poor Citizens, Nigeria Overtakes India as World Poverty Capital. Punch Newspaper. Available at https://punchng.com/with- 87 m-poorcitizens-nigeria- overtakes-india-as-worlds-poverty-capital/

[56] World Development Indicators (2018). Available at http://datatopics.worldbank.org/world- developmentindicators/

[57] International Monetary Fund (IMF) (1997). Exchange Rate Arrangements and Economic Performance in Developing Countries. Ch. 4 of World Economic Outlook.

[58] Worldatlas (2018). What Is the Richest Country in Africa? Retrieved from https://www.worldatlas.com/articles/therichest-countries-in-africa.html

[59] United Nations Development Program, Human Development Report 2007/2008 (New York: Palgrave Macmillan, 2007).

[60] Cypher, J. M. (2014). The Process of Economic Development. $4^{\text {th }}$ Ed. Routledge Taylor and Francis Group, London.

[61] Zoryan, H. (2005). The Measurement of Co-Circulation of Currencies and Dollarization in The Republic of Armenia. The European Journal of Comparative Economics 2 (1), 41-65.

[62] Mengesha, L. G. \& Holmes, M. J. (2011). The Dollarization of Less Developed Countries: A Note on the Computation of a Hard Currency Index. International Journal of Economics and Research. 2 (2), 61-66.

[63] Mwase, N.\& Kumah, F. Y. (2015). Revisiting the Concept of Dollarization: The Global Financial Crisis and Dollarization in Low-Income Countries. IMF Working Paper. 